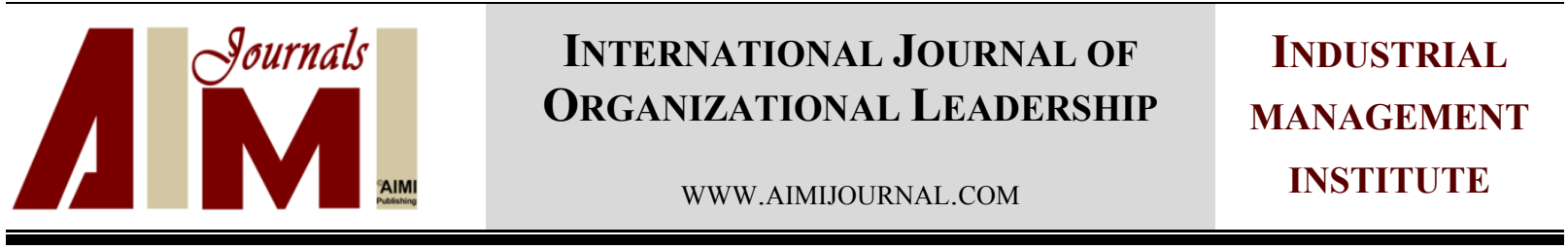

\title{
Analysis of environmental costs in the context of achieving sustainable advantage and resource based costing model proposal of reporting environmental costs: Balanced scorecard (BSC)
}

\author{
Orhan ELMACI ${ }^{*}$, Işık ALTUNAL ${ }^{2}$, Kadir TUTKAVUL ${ }^{3}$, Göksel KARAŞ ${ }^{4}$ \\ 1Department of Business Administration, Dumlupınar University, Kütahya, Turkey
}

\begin{abstract}
Keywords:

Genetic Code, Costs of Environmental Protection, Sustainable Competitiveness, Cost Advantage,

Received

13 November 2015

Received in revised form 20 April 2016

Accepted

13 June 2016

Correspondence:

oelmaci@gmail.com

Nowadays, the prevention of environmental problems and importance of elimination of this problem are among the issues which should be understood better by all disciplines. The accounting also is not insensitive to this subject-matter. This increased sensitivity for the environment has brought the concept of environmental accounting. Today, the costs of environment protection in micro-level have gained significance and will continue to increase in the future. However, the environment motive has influenced the genetic codes of firms directly or indirectly and the intensity of this effect continues to increase. Hence, in this study, it is aimed to draw the attention to increasing importance of environmental costs. The main theme of this study was primarily providing environmental costs rather than measuring it correctly. This balance is only possible with the source-based measurement model as a scorecard. Therefore, this article discusses the relationship between the socalled sustainability balanced scorecards and eco-efficiency analysis. Eco-efficiency analysis not only provides a data source for sustainability balanced scorecards but also it serves as a link between the balanced scorecard and corporate environmental accounting systems in the perspective of environmental information systems; so that, eco-efficiency as a component of an environmental information system becomes an adapter with two interfaces characterized in this article. The main focus is on the principle of cause and effect, its different forms, and the implications for the design of appropriate information system components.
\end{abstract}


Micro size reflection of the encountered economic development around the world has taken place on genetic codes of enterprises (customer, technology, product, production process/production technology, human resources, type of administration, intern climatic conditions, and institutive culture of enterprises). Gradually, these reflections (ecologically sustainable development, ESD) had to convert into sustainable development in terms of ecology by comprising ecological values. In other words, industry 4.0 converted into the fourth industrial revolution. In this regard, the enterprises which cannot adapt themselves to their environment and alter the required genetic code, changes may be eliminated by the other enterprises which are successful. To put differently, maintaining life for an enterprise which do not have competitive power is not possible under this circumstances. The competitive power of an enterprise is the indication of its ability to maintain customers which prefer its (enterprise's) products against the alternatives in a sustainable way. Sustainable competition is defined as the ability of maintaining permanency for its preferred product or service against the alternatives. There are two main components which affect the competitive power of the enterprises inclduing productivity and sustainability. Productivity involves increasing the productivity level and cost advantage in general. Sustainability includes capturing revenue opportunities and enrichment of customer value (Elmac1 \& Sevim, 2009). The term sustainability also involves utilization of natural resources, physical capital stock, human resources and technology without spoiling the law, the balance, and the feed-back of nature regarding the benefits of future generations. Besides, it is also defined as resource management which guarantees ongoing production and care about environmental, social, and economic developments. The first economist who put the term entrepreneurship energy into rooming was Richard Cantillon. Jean Babsiste Say added economical meaning and Joseph A. Schumpeter added the aspect of innovative entrepreneurship in the frame of creative vandalism theory (Elmacı \& Sevim, 2009).

The sustainability of enterprises' main abilities depends on their adaptation to changing conditions, acumen, and institutionalization. Adaptation, acumen, and institutionalization depend on the quality of non-financial qualified information. In this sense, it does not only depend on requirements of creditors and invertors from members of a profession but it also depends on fulfillment of knowledge and needs of financial and non-financial knowledge users. Therefore, the need to urge new paradigms that shall remove the weaknesses and resistances of accounting is obligatory (Elmac1 \& Sevim, 2009). In other words, accounting should be converted from an accounting which serves the state's benefits in accordance with the laws into an accounting which supports the international standards and serves the partners' and society's benefits.

The firms which ignore their ecosystems and develop their activities out of development and strategic benefit insist on spoiling the ecological balance. Spoilage of ecological balance has become a world threaten matter with synergistic effects. The arbitrary usage of natural sources by economic actors with geometrical sum has caused environmental problems. In this respect, almost all the disciplines have started to research environmental protection. Accounting is one of them which is aware of the environmental problems and has its state in the literature as environmental accounting.

It is possible to analyze environmental protection costs at micro and macro levels. The followings should be done: stabilization of the cost for utilization of nature by the users at 
macro level, removal of colonial idea, determination of natural values in national accounting, and prudential and protective precautions (Özbirecikli, 2002). Environmental protection costs have come into question at macro level. Environmental activities directly or indirectly influence the genetic codes of firms (customer, technology, and process of products' production, human resources, type of administration, intern conditions, and organizational culture of enterprise).

TAS (TMS) - 1 presentation of financial tables, the ninth paragraph of the TAS, financial state of enterprises which help to make economic decisions for users, financial performance, cash flows, the aim of financial tables, showing how effective the administrators use the resources are given. The state of entities, their exchange and conversion are subjects of accounting. Therefore, environment and the state, exchange and conversion of environmental entities are also subjects of accounting as well. In the recent years, it has been seen that the environmental costs were added to the records. Yet, the current recording system has seen that the environmental costs are reported below the calculations which are in the schedule of current account. Gradual increase in the interactions between the enterprises and the environment increases the importance of environmental costs. Reporting mentioned costs below the accounts which are in the current account planning does not tally with basic terms (concept) of accounting. These terms are social responsibility, transparency, and materiality. In this study, mainly environmental accounting which is monitored in sub-accounts is handled in the frame of environmental costs (source based costing method). Here, for manufacturers a main account group is created apart from the others. Hence, in this study, it is aimed to draw the attention to increasing importance of environmental costs. The main theme of this study was primarily providing environmental costs rather than measuring it correctly.

\section{The literature Review \\ Environmental Costs and its Classifications}

There are various definitions about environmental costs. In some definitions, environmental costs are defined as costs which are serving for environmental protection aims. And, in the other definitions, environmental costs include other cost items due to environmental performance of the enterprises, image of the enterprises, and firm price of the enterprises in addition to environmental protection costs (Schaltegger, Bennett, Buritt, \& Jasch, 2008; Ulusan, 2010). Environmental costs include both costs of environmental aims and needs and costs of attempts to manage the environmental effects of the organizational activities in an environment friendly way. Environmental resources relationship of an enterprise in achieving the sustainable competitive advantage is shown in the Figure 1. 


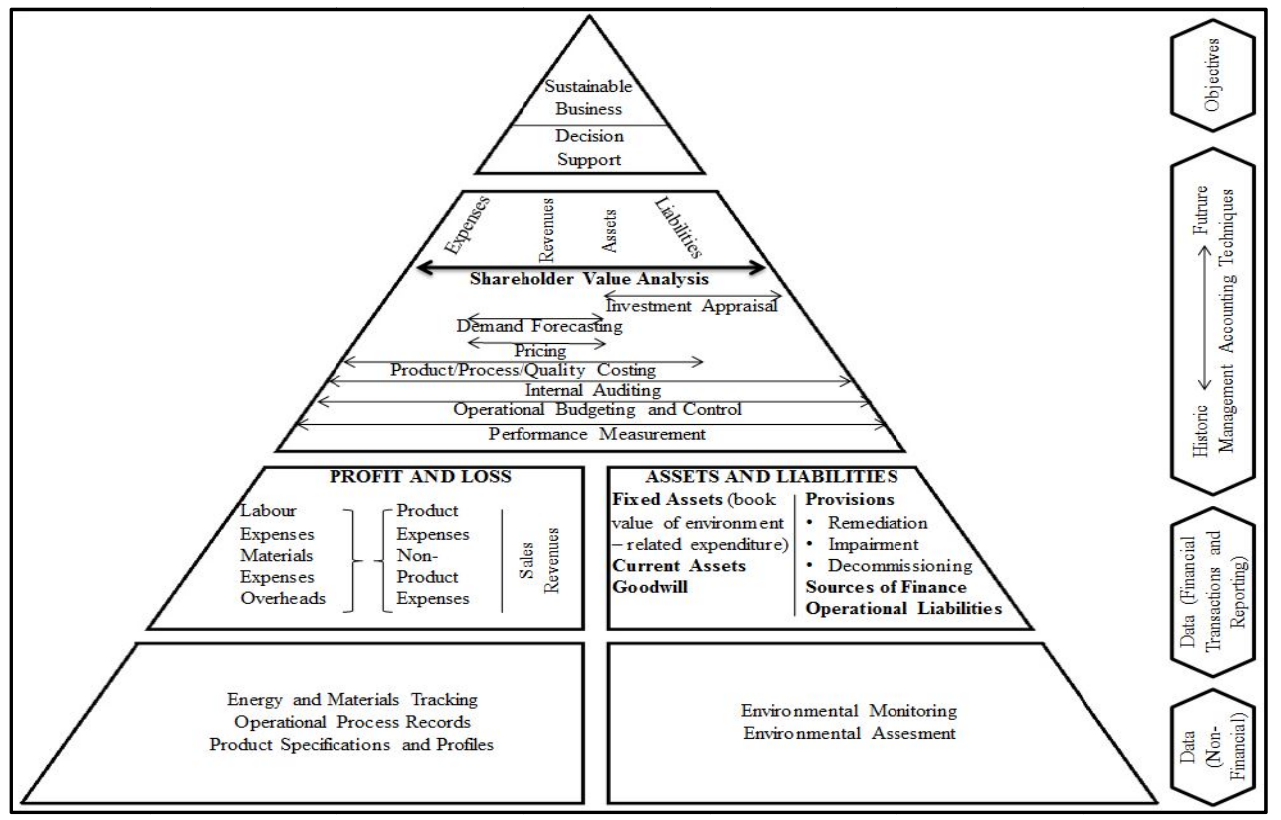

Figure 1. Environment-related management accounting pyramid

The environmental costs may be different from each other. Some of them can be observed after realizing the environmental activities while the others are seen during the use of the environmental resources. At the same time, costs that cause the environmental pollution can be seen also in some of the businesses. The environmental costs are classified as the reduced costs, operating costs, and loss costs. The environmental protection cost can be classified also as special costs and social costs. This classification is seen in Figure 2.

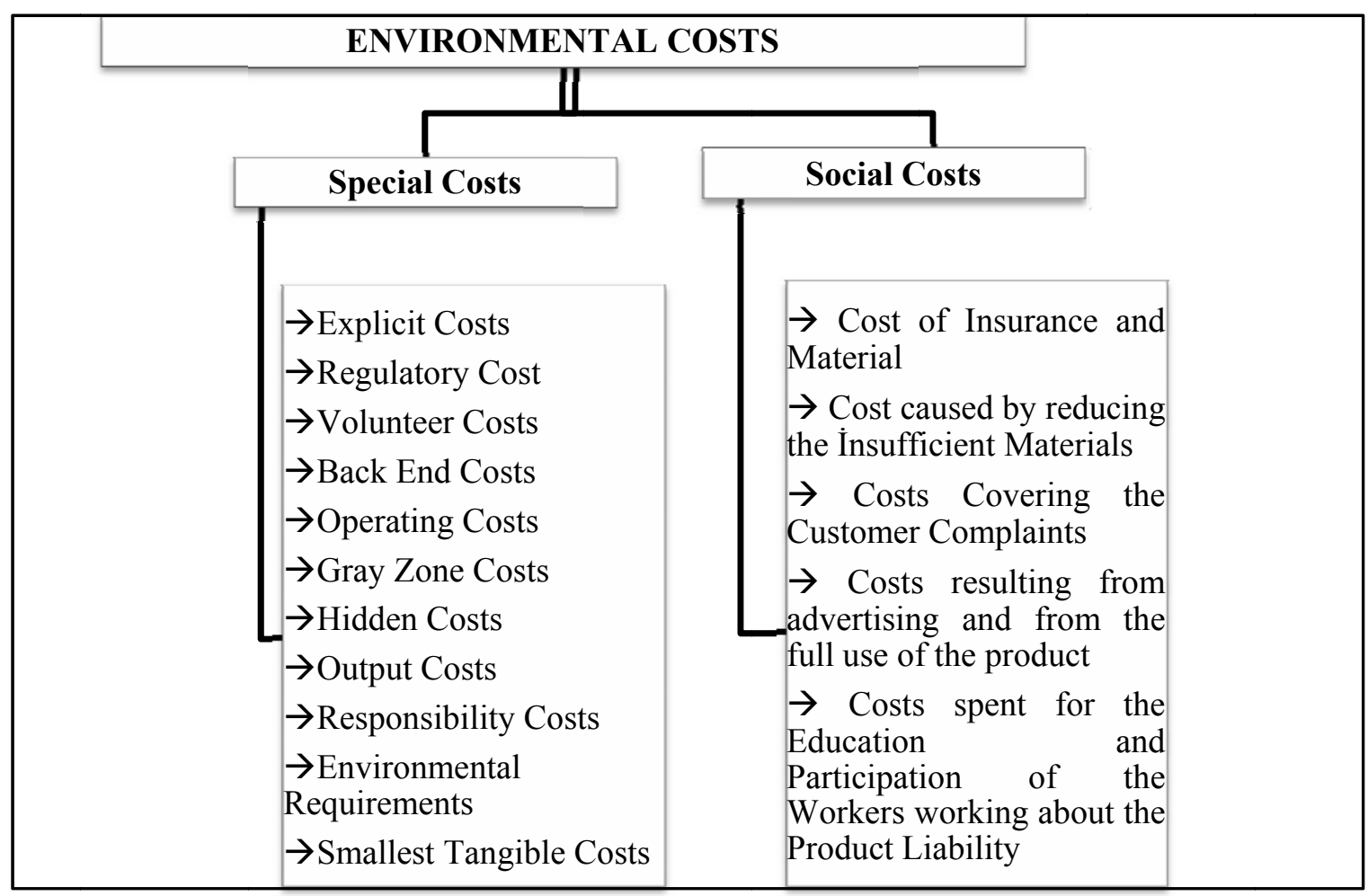

Figure 2. Classification of environmental costs 
Together with these, the environmental protection costs in the opinion of the total quality management are divided into 4 groups including protection costs, appraisal costs, internal error costs, and external error costs. Table 1 shows the relation of generic codes and environmental costs.

Table 1

Relation of Genetic Codes and Environmental Costs

\begin{tabular}{lll}
\hline Genetic Code & Environmental Affairs & Costs \\
\hline Customers & Market & Environmental Costs \\
Technology/Product Process & Tangible and Intangible Fixed Assets & Environmental Investments \\
Product & Cost of Services & Environmental Costs \\
Human Resources & General Administrative Expenses & Environmental Costs \\
Management/Organizational Culture & General Administrative Expenses & Environmental Costs \\
\hline
\end{tabular}

\section{The Place of the Environmental Protection Costs among the International Accounting Standards}

The national and international accounting organizations began working on the environmental problems faced by the institutions due to the increase in the importance of accounting. According to the reports of the Environmental Protection Agency (EPA), the environmental accounting approach has different uses and areas as the national income accounting, financial accounting, and management accounting (Özbirecikli, 2002).

In the definition of the International Financial Accounting Committee (IFAC), the environmental protection costs include the costs spent by the entities for the environmental protection. According to the International Accounting Standards, the environmental costs and responsibilities are not obligated to be explained or shown. However, the environmental costs which are important and affect the decisions to be made in paragraph 8 of the IAS5 (new situation IAS 1, paragraph 14) can be explained by showing it under a different column.

In the report of the Institute of Chartered Accountants in England and Wales under the title of "Environmental problems in financial reporting" it was emphasized to consider reduction of the costs and prevention of the environmental damages (Özbirecikli, 2002). The importance of measuring equipment and installation was stated in paragraph 16 of the International Accounting Standards and the pollution-related administrative fines and suspensions were specified in the paragraph 8 of the IAS5 (new situation IAS 1, paragraph 14).

\section{Resource Based Costing Model Recommendation for Reporting Environmental Costs in the Production Business}

The resource-based approach parallel to the traditional model of Porter which was related to the competitive advantage, emphasized the importance of resources and capabilities owned by a business in an environment where the competition was intense (Naktiyok \& Karabey, 2007). The resources position of a firm can gain sustainable competitive advantage as long as it allows the firm to create value. For this, the resources should be valuable and rare, very difficult to imitate, and the advantage they offer should not be replaceable by other sources. In addition, 
resources are required to be regulated in an appropriate manner, to be brought together, and to be placed in order to provide the sustainable competitive advantage.

The sustainable competitiveness of the businesses can be provided by general productivity and producing strategies that can change the structure of market due to the basic components of cost superiority and obtaining a significant position (moment) until they re-change the structure of market later. Then, a position which can change the structure of market can be carried out by the strategies which are created in this direction. For this, the internal and external elements of the business must be measured and the matrix which identifies this situation must be revealed within the framework of this approach. There are two approaches during the process of Corporate Performance Valuation. One of these approaches is the opportunity approach that analyses the corporate performance by a single dimension, the other one is the source approach that is analysed and examined as multi-dimensional. Balanced scorecard is the basis of the resource-based costing model. This model is supplemented with a SWOT analysis. Models showing the milestones in the strategic roadmap are shown in Figure 3. This strategic road map shows cause-effect links among learning and growth perspective, internal perspective, customer perspective, and financial perspective.

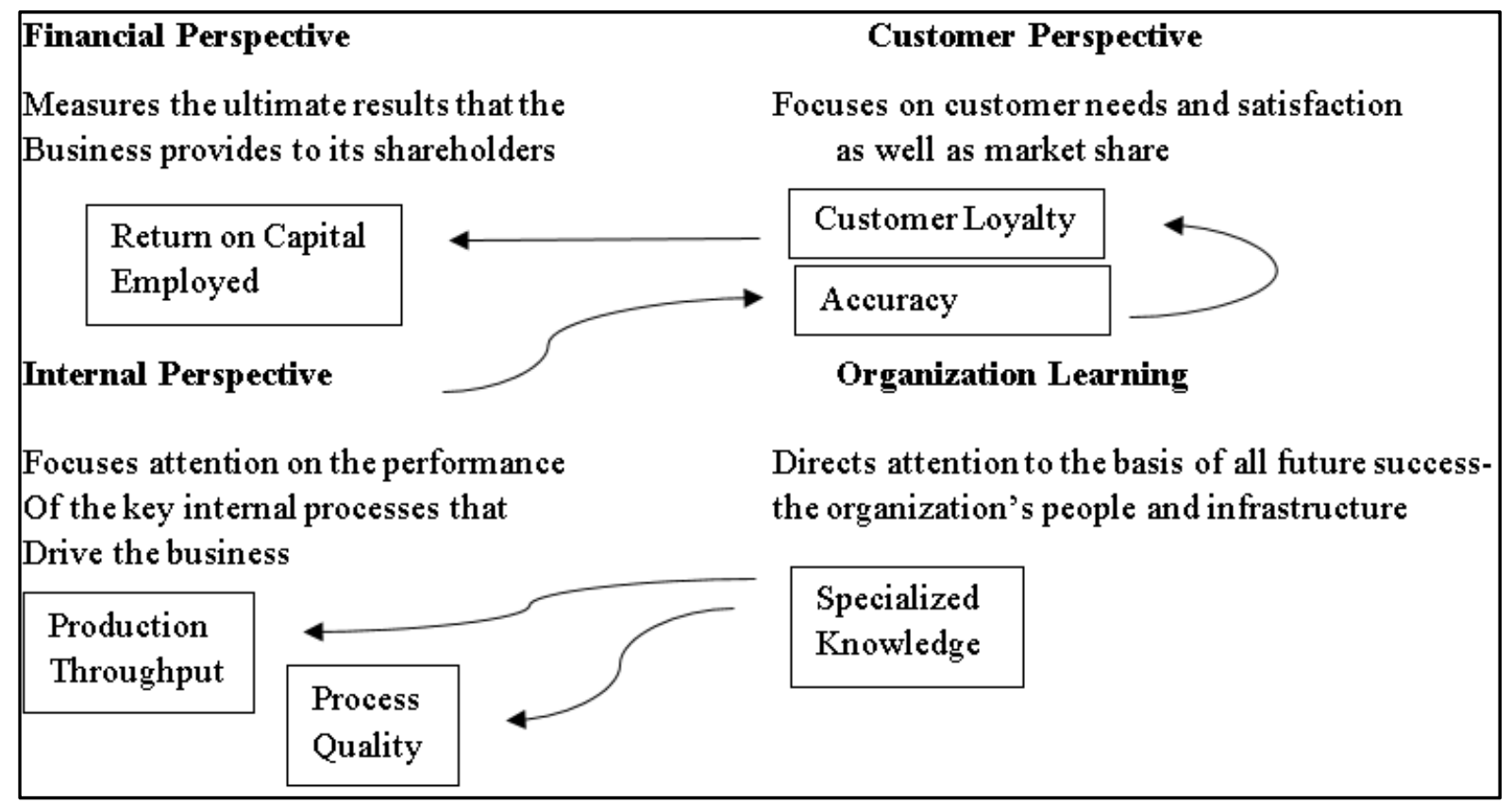

Figure 3. The cause-and-effect relationship between outcome measures and the performance drivers of those outcomes

\section{Option 1- Adding a Fifth Perspective to the BSC}

This perspective consists of social and environmental performance indicators that link with the other four BSC dimensions and highlight the importance of social, environmental, and economic responsibility as a corporate goal.

\section{Option 2- A Sustainability Balanced Scorecard}


A separate SBSC also can be used by companies which want to emphasize corporate sustainability as a key value or critical strategy without revising the original BS format.

Option 3- Integrating sustainability measures throughout the four perspectives sustainability metrics can be added to or substituted from some existing measures and no major changes to the BSC structure or reporting are likely to be required. Integration is also useful for companies that are in the BSC development stage and it is necessary to highlight the sustainable development practices.

In balanced scorecard long-term and short-term financial and non-financial criteria, all the company has to do is to create balance between stakeholders. This is to take into account the environmental factors to be exact so the balance of performance of the operator to get a more accurate way of measuring will be done in a milestone move. Because measurements are made without environmental costs, business performance measurement will remain inadequate. In other words, long-term balance between short-term goals by the target will not be revealed exactly. To be a long-term basis, it should be the basic ability of the company to be sustainable to achieve lasting success. On the other hand, achieving success in the short-term objective in terms of common and shareholders is required. Resource-based vision (RBS-Resource-Based View of Firm) institutions of knowledge and skills created to face the capabilities of strategic / basic ability to convert all the remote and close environmental factors of business activities impact on the business. The business should be mobilized to ensure lasting success/ managed envisages a strategic approach. This approach has many functions in the organization and environmental factors mutual Fiction (speculative) Model including fractal spiral in the network framework and the creation of a dynamic "strategic intent" to pave the way for ensuring of cohesion. All activities of the company which are able to talk about the business of the input-output balance are needed to be measured embedded with environmental factors. These criteria measuring the business performance/ evaluation, and control are also available. The criteria are that the strategy adopted should be paralleled with strategic management. In this context, the results card will be created when the long-term goal and short-term targets is expected to take place in a balanced manner. Short-term and long-term goals will be noted to move an important milestone in the acquisition and succession conducted a short-term strategic objective that brings long-term success. The results of card business under a scheme should be established. Environmental factors together with the criteria information about the company's operational results in Precursors which will provide an increased degree of reliability of measurement used in the nature of environmental criteria.The long-term increasing strategic importance of lasting success management process carries the key to success in business location. Especially transfer the businesses strategies to employees, and implementing and measuring performance. Given the problems experienced at times, the result card designed with environmental criteria businesses will help to solve this problem. This model's success comes from environmental needs of the business to be accurate determination of cause and effect relationship in business strategy consisting of performance criteria reflecting the results of design of the card and the measurement must be accurate and realistic. To correctly implement the method of application, the model will play an important role in the realization of the intended target. Other criteria such as environmental criteria used in the balance of the card 
should be monitored regularly. These criteria encountered various difficulties in rendering automatic determination method. The analysis is carried out of the situation so it would be appropriate to take the necessary precautions environmental criteria to be suitable for the sustainable success of the company.

There should be no doubt that the basis will be transparent and objective criteria. Performance cannot control the unrealistic and employees' measures should also be included in the result card. Moreover, the environmental performance criteria conditions will be in place and be updated according to the state of the business. The fictionalized true cause-effect relationships, size, and accurate determination of the business logic of the relationship between fiction targets face difficulties. You will also need to pass a map that one of the basic points in the strategy approach is the assumption that there is a connection between the strategic profile of the firm and the external environment regardless of which perspective you are looking. The strategic management allows coping with the uncertainty by shaping the competitive environment of the organization. The company with the strategic orientation defines its environment, responds to the element accepted as data, and adopts a strategy based on the needs of the environment. The classification which was developed in terms of the strategic orientation, parallel with the resource -based approach, sees the organization as an integrated system that interacts constantly with its environment.

The type of the strategy selected by the firm actually depends on the perceptions of the top management related to the environmental conditions and on the decisions taken about how to cope with these conditions. A strong relationship was determined between the perception of the environmental degradation and the analyser strategies.

\section{Research Hypothesis}

The following hypothesis guided the study:

- According to the degree of the business environment's negative perceptions the type of the adopted strategy is differentiated (Naktiyok \& Karabey, 2007).

The ability to use the assets (tangible, intangible) in a manner that increases the level of the cost superiority and the overall productivity determines the talent of the entity. This ability must be qualified as valuable, rare, inimitable, and non-substituted to become a basic ability. This basic ability must have the feature to adapt to the changing environment to become a sustainable basic ability. The BSC combines nonfinancial and financial measures in the internal corporate reporting process so that managers can assess the efficacy of strategic plans and actions.

The entity must divide all the activities into two groups including value creating and noncreating activities to reach its aims. In other words, starting with the approach of "creating a value for the customers" each of the activities need to be grouped by creating or not creating an added value for the products produced by the entity. Because of the value added to the entity's product by the activity, its cost is expected to be more than the cost of the activity. If the value added by the activity is lower than the cost of the activity, it means that the activity did not create any value. 
The value which was added to the manufactured products by all these activities must be bigger than the value which was acquired by the activities of the competitors in order to achieve competitive advantage for the business. Otherwise, even if the business creates value, it cannot obtain competitive advantage. The values that can provide competitive advantages as a result of the activities in the entities, occur in two ways; by reducing the cost of the activities through the provision of value increase through achieving cost advantage and through creating a difference which is appreciated by the customers in the product and in return applying a price above the market price by creating an increase in the value.

The activities made in the entities can be collected into two groups including main activities and support activities. The value (income) generating activities are classified into five main groups, namely internal-oriented logistics, production, external-oriented logistics, marketing and Sales, and services. The support activities which support the basic activities of the business and thus, contribute to the creation of value can be categorized into four main groups including infrastructure procurement, technological development, human resource management, and managerial infrastructure of the business.

Besides handling with both internal and external sizes of the cost for which the business is responsible and incurred, the cost that occurred due to the company's operation but was not held responsible and was not paid must be taken also into consideration. These costs seem not to affect the business in short term but have a great possibility to affect the business in long term (Özbirecikli, 2002). Nowadays, the increasing environmental problems force the businesses to be more sensitive to environmental issue and to identify its environmental costs and debts in a correct way. The entities have to create an effective system for environmental accounting and the information acquired by this system must be used to take appropriate decisions for the benefit of the natural environment and itself. Especially in terms of taking the necessary precautions, it is very important to know not only in which business section these environmental costs occurred, but also from which sub-elements they were resulted (Özbirecikli \& Melek, 2002).

It is very difficult to detect and deliver these environmental costs. However, useful management accounting techniques were developed for the identification and distribution of the environmental costs; for example, it was developed for the input / output analysis, current cost accounting, activity-based costing, and life cycle costing. The traditional cost accounting methods are insufficient for the direct distribution of the products related to environmental costs. Removal of the negativities in the distribution of the environmental costs distributed by the traditional distribution methods and in relation to the installation of the products and production processes which are related to the usage of Resource Consumption Accounting methods (RSA) which is an old version of the Resource-Based Approach will be an appropriate application. The application of the RSA methods with the environmental accounting in an integrated manner was summarized at three stages which are touched upon briefly below.

Analysis of the Resources: At this stage, the resources which are used in the manufacturing of the product are determined, the resources with close functions are combined, and as a result the production activities are revealed. For example, in terms of environmental accounting, 
management of the waste arising during the manufacturing of the product, control of the raw materials in terms of environmental damages, the purification process of each product are resources.

Identification of the Resource Costs: At this stage, the costs of the activities determined at the first step are identified monetary. When the issue is associated with the environmental accounting, the costs of the resources given as examples in the first step are determined.

Key Distribution of the Resource Consumption Costs related to the Products: This is the stage to distribute precisely the data obtained from the first and second stage of the product. The most important part of this step is the selection of the key on which the distribution will be based. For this, two basic factors should be considered. One of these is the high degree of interest between the activity and the key determined for the source and the other is measurement cost of the specified key.

The cost information obtained by administration of the three stages in the RSA application summarized above will be more accurate and reliable according to the information obtained by the traditional cost accounting methods. The management oriented environmental management and the resource -based costing as an essential and analytical approach are needed when determining the environmental costs and expressing the cost savings in figures in order to introduce and develop the environmental performances.

The environmental accounting can be defined as accounting the environment-related financial qualifications and showing them in the financial statements (Gökgöz, 2012). In this context, when accepting the environmental accounting as a distinct discipline it should include all the functions of the accounting discipline. When considered in this context, the scope of the environmental accounting information system's functions is listed as recording which is the process of recording the environmental costs with fiscal nature in the daily book according to the documents; classification which is the process of transferring the environmental costs which were recorded in the daily book in the ledger; reporting which is the process of presenting the environmental costs with fiscal nature which was recorded in the daily book then in the ledger with the help of financial statements to the concerned ones; and reporting which is the process of presenting the environmental costs with fiscal nature which was recorded in the daily book then in the ledger with the help of financial statements to the concerned ones.

\section{Recording the Environmental Costs which have Financial Nature into the Model of Environmental Accounting Information System}

Accounting is an information system that produces information. This information is expected to be accurate, relevant, full, in time, accessible, understandable, reliable, and efficient. Therefore, the information created by the accounting system needs to be quality information. In order to record the environmental costs, separate accounts are required in the traditional accounting system. The suggestion for the foreseen account plan changes for the recording of the environmental costs in this model is as given in Table 2. 
Table 2

The Suggestion for the Account Plan related to Cost Accounts

\begin{tabular}{|c|c|}
\hline \multicolumn{2}{|r|}{ Accounts of Environmental Cost } \\
\hline Account Code & Name of the Account \\
\hline 81 & Environmental Direct First Substance and Material Expenses \\
\hline 810 & Account of the Environmental Direct First Substance and Material Expenses \\
\hline 810.10 & Reducing Expenses \\
\hline 810.20 & Using Expenses \\
\hline 810.30 & Loss Expenses \\
\hline 810.40 & Environmental Other Expenses \\
\hline 811 & Reflection Account of the Environmental Direct First Substance and Material Expenses \\
\hline 82 & Environmental Direct Labor Expenses \\
\hline 820 & The Account of the Environmental Direct Labor Expenses \\
\hline 820.10 & Reducing Expenses \\
\hline 820.20 & Using Expenses \\
\hline 820.30 & Loss Expenses \\
\hline 820.40 & Environmental Other Expenses \\
\hline 821 & Reflection Account of the Environmental Direct Labor Expenses \\
\hline 83 & General Environmental Production Expenses \\
\hline 830 & General Environmental Production Expenses \\
\hline 830.10 & Reducing Expenses \\
\hline 830.20 & Using Expenses \\
\hline 830.30 & Loss Expenses \\
\hline 830.40 & Environmental Other Expenses \\
\hline 831 & Reflection Account of the General Environmental Production Expenses \\
\hline 84 & Cost of the Environmental Service Production \\
\hline 840 & Cost of the Environmental Service Production \\
\hline 840.10 & Reducing Expenses \\
\hline 840.20 & Using Expenses \\
\hline 840.30 & Loss Expenses \\
\hline 840.40 & Environmental Other Expenses \\
\hline 841 & Reflection Account of the Environmental Service Production Expenses \\
\hline 85 & Expenses of the Environmental Research and Development \\
\hline 850 & Account of the Environmental Environmental Research and Development Expenses \\
\hline 850.10 & Reducing Expenses \\
\hline 850.20 & Using Expenses \\
\hline 850.30 & Loss Expenses \\
\hline 850.40 & Environmental Other Expenses \\
\hline 851 & Reflection Account of the Environmental Service Production Expenses \\
\hline 86 & Expenses of Environmental Marketing, Selling and Distribution \\
\hline 860 & Account of the Environmental Marketing, Selling, and Distribution Expenses \\
\hline 861.10 & Reducing Expenses \\
\hline 860.20 & Using Expenses \\
\hline 860.30 & Loss Expenses \\
\hline 860.40 & Environmental Other Expenses \\
\hline 861 & Reflection Account of the Environmental Marketing, Selling, and Distribution Expenses \\
\hline 87 & Environmental General Administrative Expenses \\
\hline 870 & Account of the Environmental General Administrative Expenses \\
\hline 870.10 & Reducing Expenses \\
\hline 870.20 & Using Expenses \\
\hline 870.30 & Loss Expenses \\
\hline 870.40 & Environmental Other Expenses \\
\hline
\end{tabular}




$\begin{array}{cc}871 & \text { Reflection Account of the Environmental General Administrative Expenses } \\ 88 & \text { Environmental Financial Expenses } \\ 880 & \text { Account of the Environmental Financial Expenses } \\ 880.10 & \text { Reducing Expenses } \\ 880.20 & \text { Using Expenses } \\ 880.30 & \text { Loss Expenses } \\ 880.40 & \text { Environmental Other Expenses } \\ 881 & \text { Reflection Account of the Environmental Financial Expenses }\end{array}$

Table 3 presents the suggestion for the plan account related to balance sheet accounts.

Table 3

Suggestion for the Plan Account related to Balance Sheet Accounts

\begin{tabular}{cc}
\hline Environmental Balanced Sheet Accounts & \\
\hline Account Code & Name of the Account \\
\hline 25 & Tangible Assets \\
256 & Other Tangible Assets \\
256.09 & Environmental Tangible Assets \\
258 & Ongoing Investments \\
258.09 & Investments in Environmental Protection \\
26 & Intangible Assets \\
263 & Research and Development Expenses \\
263.09 & Environmental Research and Development Expenses
\end{tabular}

The complex accounting of the environmental costs in businesses which operate in different areas and different activities does not coincide with the basic principles of accounting. But the persons who are concerned with general accounting and recording environmental costs provide neither regular control nor full reporting. Thus, the information regarding the environmental costs must be considered very carefully and should be shown open and separately in the accounting records. The environmental information should be shown in the chart of accounts and this information should be documented. The next step after the documentation is recording. The documents about the environmental protection costs should be recorded and should be shown in the chart of accounts. Unfortunately, in the last accounting plan there was no detailed account part.

In the field of the environmental protection activities, the businesses attempt to prevent the pollution which occurs as a result of their investment. These kinds of investments should be included in the assets of the businesses' balance sheet. Two recommendations were developed in order to open current accounts: The investing accounts should be opened when opening environmental costs and the investment is completed. The appropriate asset account in the group of the $25^{\text {th }}$ tangible assets should be transferred to the account plan. The activities carried out in order to protect and develop the environment should be activated in the group of $26^{\text {th }}$ Intangible Assets. Following this, the researches, activities, and environmental costs which were made to minimize the possible negative reactions of the society, emphasize the importance of the product, increase the value of the organization in the eyes of the stakeholders and improve, should be followed in a separate account plan. These accounts may be in the form of environmental costs, investments for environmental protection, and future investment protection. 
Table 4

Classification of Environmental Costs

\begin{tabular}{|c|c|}
\hline Environmental Cost Groups & Types of Environmental Costs \\
\hline \multirow{23}{*}{ Reduce Costs } & Environmental Planning Costs \\
\hline & Process Control Costs \\
\hline & Emissions Measurement Equipment Costs \\
\hline & Harmless Product Design Costs \\
\hline & Recycling Operating Costs \\
\hline & Harmless Packaging Design Costs \\
\hline & Environmental Development Costs \\
\hline & Environmental Education Costs \\
\hline & Laboratory Services Costs \\
\hline & Environmental Engineering Services Costs \\
\hline & Environmental Reporting Costs \\
\hline & Environmental Labeling Costs \\
\hline & Environment Reliability Costs \\
\hline & Environmental Information System Costs \\
\hline & Environmental Management System Costs \\
\hline & Environmental Audit Costs \\
\hline & Environmental Handbook Costs \\
\hline & Product Liability Insurance Costs \\
\hline & Waste Control Costs \\
\hline & Waste Disposal Costs \\
\hline & Waste Treatment Costs \\
\hline & Research and Development Costs \\
\hline & Other Reduce Costs \\
\hline \multirow{10}{*}{ Exploitation Costs } & Air Costs \\
\hline & Water Costs \\
\hline & Soil Costs \\
\hline & Noise Costs \\
\hline & Image Costs \\
\hline & Gas Costs \\
\hline & Oil Costs \\
\hline & Coal Costs \\
\hline & Other Energy Costs \\
\hline & Other Exploitation Costs \\
\hline \multirow{11}{*}{ Loss Costs } & Air Pollution Costs \\
\hline & Water Pollution Costs \\
\hline & Soil Pollution Costs \\
\hline & Noise Pollution Costs \\
\hline & Image Pollution Costs \\
\hline & Penalties - Compensation Costs \\
\hline & Environmental Cleanup Costs \\
\hline & Complaint Costs \\
\hline & Warranty Costs \\
\hline & Sales Decrease Costs \\
\hline & Other Loss Costs \\
\hline
\end{tabular}

In summary, there are two important mainstays associated with the environmental protection costs. The first is the internal or private cost which is directly related to the events affecting the profit or loss. The second is the social cost affecting the profit or loss indirectly as a result of the activities. With the more and more increasing environmental awareness, the costs of the firms spent for the protection of the environment are increasing today. Therefore, this type of costs should not be assessed by the overall costs, but should be included in the quality costs. 
The environmental protection costs are divided into two groups including private/ internal and social costs. These costs should not be associated directly with the production. Therefore, it is necessary to follow the environmental costs in separate accounts. The opening of the account plan is expected to ease the recording, classifying, reporting, analysing, and interpreting of the environmental costs with fiscal nature due to the foreseen accounts.

\section{Classification of Environmental Costs with Fiscal Nature in the Model of Environmental Accounting Information System}

In the developed model, the general ledger is used for the classification of environmental costs which were recorded to the cash blotter within the foreseen accounts chart based on the documents. During the classification process in the ledger, it can be utilized from the different kinds of environmental costs. The environmental costs are classified both on the basis of function and varieties due to the accounts charts which was developed by recommendation of the environmental accounting information system model. Environmental costs are classified in Table 4 (Gökgöz, 2012).

Thanks to this accounting plan developed by environmental accounting information system model proposal, environmental costs are classified according to both kinds and functions.

\section{Reporting the Environmental Costs with Fiscal Nature in the Model of Environmental Accounting Information System}

The environmental costs with fiscal nature which were classified and recorded in the model of environmental accounting information system are reported through financial statements. It is stated below how the use of No. 8 account in the account chart reflects the financial reporting.

\section{Recording the Current Term Transactions}

The environmental costs with fiscal nature occurred during the current period in the manufacturing firms are followed in the No. 8 Environmental Cost Account. The expenses associated with the environmental costs should be recorded in the debt of the cost accounts related to the basis of the sub-accounts, in the receivables of the related assets or debt accounts.

\section{Recording the Period-End Transactions}

In the manufacturing businesses at the end of the period, the environmental costs with fiscal nature which were followed in the No.8 Environmental Cost Account are transferred to the income statement and balance sheet accounts through the reflection accounts.

When transferring the environmental costs associated with the product to the balance sheet at the end of the period, they are transferred primarily to the semi-finished products' production account from there to the finished goods account.

The environmental costs associated with the service production are transferred to the income statement account at the end of the period. The environmental costs associated with the operating activities are transferred to the income statement accounts at the end of the period. 


\section{Interpreted Analysis of the Environmental Costs with Fiscal Nature in the Model of Environmental Accounting Information System}

The environmental costs emerging in the manufacturing entities are recorded, classified, and reported in accordance with the model of environmental accounting information system. Finally, the reported environmental costs are analysed by interpreting it in a way which is appropriate to the common needs of the financial statements' users. The cost of products which were manufactured through the recommendation of this model can be analysed separately as production costs and environmental costs.

\section{Discussion and Conclusion}

This model in terms of profitability of businesses will be negatively affected due to increased costs in the short term, however, it is obvious that long-term positive impact can contribute to product differentiation in the market, as well as increase the image of the business to both existing and potential customers and investors which in turn will lead to increased profitability of the company.

The sustainable competitiveness is the implementation of value creation strategy that can help the business to stay different despite the imitation efforts of the current and future competitors. The competitiveness originates from the lower process costs (by the economies of scale, economies of scope and factor costs) and /or from the differentiation of the product (different quality of the product or the product has features that give value to the customers, the entity has featured geographical location, the company has special skills or different service provisions). A balance needs to be established between the two types of strategies to achieve sustainable competitiveness. These two strategies are the living strategy and the progress strategy. A proper balance will be provided between the living and progress strategies by the "Value Chain Analysis". It is mandatory to create the "Resource-Based Costing" system in the business to measure the value-generating activities of the business. Nowadays, the accurate identification and analysis of the environmental costs is an important argument in ensuring the cost superiority which is the key component of the competitiveness. Analysis of the cost of resource consumption and its contribution to the customers, products and supply chain is getting increasingly important for the entities. Recording and evaluating the cost and services of the resource consumption is extremely difficult in the resource consumption calculations due to the complexity of the resources and due to the fact that the cost accounting systems were not designed according to these activities. Therefore, the ability to measure whether the activities, which are the cost elements, added higher value to the product of the entities than it had before can be only provided by the "Value Chain Analysis" methods by mapping the processes of resource consumptions correctly.

The entities carry out the environmental pollution and the consumption of natural resources. They damage the natural balance. This awareness has become an extremely important topic for both the society and the national environmental regulations. The managers considering the selfpriority concept and the concept of social responsibility in the external and internal reporting should be sensitive about this evolving process and should take effective decisions. Otherwise, the businesses will use their competitiveness and, at the same time, they may feel the danger of facing the risk of disappearing forever. 
Thanks to the recommendation of this developed model, the businesses will make reporting by adhering to the concept of social responsibility and materiality. In addition, monitoring of the environmental costs in a separate account will facilitate control of it and this will present more relevant and more reliable information in terms of the information users.

\section{References}

Elmac1, O., \& Sevim, Ş. (2009). Analysis of logistic process costs in determining success strategy with the resource-based approach in providing sustainable competitive advantage. The international symposia modern developmental trends and Turkıc world, Khazar Unıversity, Bakü, 29-31 Mayıs.

Gökgöz, A. (2012). Social Aspects of Accounting. Bursa: Dora publishing.

Naktiyok, A., \& Karabey, C. (2007). İşletmelerin maddi ol-mayan kaynakları ve çevresel olumsuzluk algıları ile stratejik yönelimleri arasındaki ilişki. Ankara Üniversitesi SBF Dergisi, 62(4), 203-225

Özbirecikli, M. (2002). Environmental accounting. Ankara: Naturel publishing.

Özbirecikli, M., Melek, Z. (2002). Çevre muhasebesi ve çevresel maliyetlerin maliyet muhasebesi sistemine etkileri ve bir araştırma. Muhasebe ve Finansman Dergisi, 14, 82-91.

Schaltegger, S., Bennett, M., Buritt, R. L., \& Jasch, C. M. (2008). Environmental management accounting for cleaner production. New York: Springer Science.

Ulusan, H. (2010). Examining in terms of recognition and reporting of environmental costs and liabilities in turkey accounting/financial reporting standard. Journal of Social \& Economic Research, 13(19), 75-99. 